\title{
Kultura piśmienna Irlandii we wczesnym średniowieczu
}

I rlandia znajdowała się poza zasięgiem politycznym i kulturalnym Cesarstwa Rzymskiego, a więc również poza zasięgiem wpływów kultury ـ lacińskiej. W pierwszej połowie V w. nastapila chrystianizacja Irlandii. Tradycja przypisuje dzieło chrystianizacji tej wyspy św. Patrykowi i jego towarzyszom. Być może jednak dzialały tutaj w V w. również inne grupy misjonarzy. Kronika Prospera z Akwitanii (zm. po 455) wspomina o jednym takim misjonarzu - biskupie Palladiuszu. W tradycji jednakże Patryk uchodzi za apostoła Irlandii, pierwszego i największego świętego iryjskiego, który w tekstach hagiograficznych i kulcie przejął cechy celtyckiego bohatera mitycznego - jak dowiódł tego w pięlknym studium Stefan Czarnowski. Patryk zapewne czas jakiś spędził w biskupich i monastycznych ośrodkach Galii (Auxerre, Lérins) i do Irlandii przybył juz jako biskup misyjny, by - jak zanotował w swej „Confessio” (Spowiedź) - głosić Ewangelię „aż do miejsca, gdzie nie było już żadnego człowieka” i uczynić „z Iryjczyków lud Pana”. Siedzibą biskupią Patryka był zapewne położony w północnej części wyspy klasztor Armagh. Tu również znajdowała się siedziba najważniejszego wówczas na wyspie króla. Klasztor Armagh stał się w czasach późniejszych siedzibą metropolity Irlandii.

Razem $z$ misjonarzami dotarła do Irlandii chrześcijańska kultura piśmienna, lacińskie pismo i książka. Wprawdzie znane tu było zapewne pismo rodzime, ogamy. Używano go jednak do krótkich inskrypcji, nie zaś do pisania tekstów lub książek. Tradycyjna literatura Irlandii przekazywana była drogą pamięciową i istniala długo jeszcze jedynie w przekazie oralnym.

W tym świecie kultury oralnej Irlandii celtyckiej dzialały grupy kapłanówdruidów, których obszarem była religia, magia i sprawy polityczne. Działały również grupy filidów - być może konkurujących z druidami. Filida był poetąśpiewakiem i mędrcem, znawcą przeszłości plemiennej, strażnikiem poezji epickiej i mitologicznej. Filidzi - może jako rywale druidów - znaleźli swe miejsce w społeczeństwie chrześcijańskiej Irlandii. Ich twórczość wtapiała się w łacińską kulturę piśmienną, uprawianą w klasztorach. To połączenie tradycji rodzimej i lacińskiej-uczonej było cechą specyficzną piśmiennictwa iryjskiego i walijskiego wieków średnich. Rękopisy z tekstami opowieści epickich i mitycznych kopiowano w klasztorach. Jako pierwsi wprowadzili Iryjczycy także język rodzimy do tekstów pisanych, do szkól klasztornych i nauczania. W łacińskich rękopisach klasztornych pojawiają się glosy (pojedyncze wyrazy lub krótkie zdania), komentarze, modlitwy i wiersze, pisane w języku rodzimym.

W okresie działania misjonarzy chrześcijańskich celtyccy Iryjczycy żyli w świecie plemiennym. Był to świat rolników-pasterzy i wojowników; kraj bez miast i śladów rzymskiej administracji, która była podstawą organizacji Kościoła lacińslkiego we wczesnym średniowieczu. Podstawową jednostką społeczną był 
wówczas w Irlandii ród, zaś formacją polityczną - plemienne państewko (thúath) $z$ królem na czele. Początkowo istniało setki takich drobnych królestw i dopiero stopniowo ukształtowało się pięć większych królestw - prowincji.

Misjonarze chrześcijańscy wprowadzili do Irlandii tradycyjną już organizację „Kościoła episkopalnego” („Kościoła biskupiego”), którego podstawowa jednostka (diecezja) pokrywała się $z$ obszarem królestwa plemiennego. Już jednak za czasów św. Patryka pojawiły się w Irlandii klasztory mnichów i mniszek; były one ważnymi ośrodkami życia religijnego. Cała grupa sławnych klasztorów powstała w VI w. Św. Brygida (zm. ok. 523) utworzyła podwójny (dla mnichów i mniszek) klasztor Kildare; św. Finnian (zm. ok. 550) założył Clonard, klasztor słynny z dużej liczby świętych, jacy stąd wyszli. Jednym $z$ nich był św. Comgall (zm. ok. 601). Najbardziej jednak sławnym twórcą klasztorów był św. Kolumba (zm. 597), nazywany w języku rodzimym Columcille („Gołąb Kościoła"). Tradycja przypisywała mu założenie 300 klasztorów, a w każdym $z$ nich miał pozostawić własnoręcznie pisany Ewangeliarz. Mnich z Sankt Gallen Notker Balbulus pisał w IX w., że św. Kolumba „był twórcą, zalożycielem i przełożonym wielu klasztorów oraz kościołów" (multarum cellarum, id est monasteriorum vel ecclesiarum institutor, fundator et rector extitit). Kolumba pochodził $z$ rodu królewskiego, a dzięki takim koneksjom rodowym, możnym krewnym i zapałowi religijnemu mógł rzeczywiście wiele zrobić dla rozszerzenia monastycyzmu iryjskiego. Jego dziełem było założenie klasztoru Derry (około 546), Kells (550), Durrow (około 553) i słynnego klasztoru Iona (563), położonego na niedużej wysepce u wybrzeży kraju Piktów (Szkocji).

Od VII w. klasztory w Irlandii stały się najważniejszymi ośrodkami życia kościelnego. Opat był nie tylko zwierzchnikiem swojego klasztoru; podlegali mu również zamieszkujący olkolice klasztoru chrześcijanie. Opat byl ich panem i wykonywal sąclownictwo kościelne. Duchowieństwo tworzyli najczęściej mnisi. Klasztory iroszkockie związane były ze światem zewnętrznym jeszcze w inny sposób. Oto urząd opata był często dziedziczny w rodzie założyciela lub możnego fundatora dóbr klasztornych. Zwykle opat spokrewniony był z rodem królów plemiennych, którzy patronowali klasztorowi. W ten sposób organizacja klasztorna dostosowana została do struktury rodowej społeczeństwa Irlandii.

Wszystko to prowadziło najpierw do osłabienia, a potem do zaniliu struktury diecezjalnej Kościoła episkopalnego; spowodowało ukształtowanie się specyficznej organizacji Kościoła iroszkockiego we wczesnym średniowieczu. Opat był glówną postacią życia kościelnego, zwierzchnikiem adninistracji kościelnej. Podległy mu biskup pełnił jedynie funkcje duszpasterskie i liturgiczne, był jednym $z$ mnichów mieszkających w klasztorze. Czasem tylko urząd opata połączony był z godnością biskupa. Św. Kolumba był opatem klasztoru Iona i kapłanem, ale nigdy nie był biskupem. Anglosaski kronikarz Beda Czcigodny (Venerabilis) napisal w początkach VIII w., iż osobliwością „Kościoła św. Kolumby" było to, że kierował nim zawsze kapłan a nie biskup. W Kilclare św. Brygida wyznaczyła jednego $z$ mnichów-eremitów, by został wyświęcony na biskupa. W ten sposób klasztor ten stal się jednocześnie siedzibą biskupa.

Każdy klasztor i jego okręg duszpasterski (zwany paruchia, od lac. parochia), kierowany przez opata, stanowił samodzielną jednostkę kościelną. $Z$ czasem jednak - w oparciu o władzę polityczną królów „naczelnych”, królów prowincji - 
powstawały wielkie opactwa, opactwa główne, którym podlegały klasztory lokalne. Tak np. klasztor Iona stał się centrum kościelnym królestwa Dal Riáta (Dalriada), obejmującego północno-wschodnią Irlandię i część Szkocji. Tworzyły się zatem związki klasztorne, na czele $z$ opactwem głównym, które przypominały metropolie w organizacji średniowiecznego Kościoła. Klasztor św. Brygidy - Kildare, główne opactwo prowincji Leinster, nosiło nazwę „urbs metropolitana”, zaś biskup klasztorny nazywał się ,archiepiscopus”. Tak samo klasztor Armagh, założony według tradycji przez św. Patryka i będący jego glówną siedzibą, od VIII w. uważany był za metropolię prowincji Ulster.

Odrębność organizacyjna Kościoła iroszkockiego nie była jedyną cechą wyróżniającą go od innych Kościołów krajowych wczesnego średniowiecza. Istniały ponadto pewne różnice obyczajowe i obrzędowe, takie jak inny kształt tonsury duchownych, inny sposób wyznaczania daty Wielkanocy. Iroszkocki Kościół monastyczny wyróżnial się także surowością praktyk ascetycznych i szczególnym znaczeniem pokuty w życiu klasztornym. Pokuta miala charakter kary za grzechy i przewinienia - często kary fizycznej, jak post, zamknięcie w karcerze, chłosta. Pojawil się nawet nowy rodzaj ksiąg, penitencjały - księgi pokutne („Libri poenitentiales”), zawierające szczegółowe taryfikatory polzutne. Najstarszy taki penitencjał pochodzi od św. Finniana, a najważniejszym był penitencjał Cummeana $z$ polowy VII w.

Do praktyk ascetycznych iroszkockich mnichów należała też węclrówka, „pielgrzymowanie w imię Chrystusa” (peregrinatio pro Christo). Dla tych ludzi wrośniętych w krąg rodu, w swojski świat rodziny klasztornej, przywiązanych do ziemi swego urodzenia, największym wyrzeczeniem było porzucenie bliskich i ziemi rodzinnej, kraju. Piszący w pierwszej połowie IX w. Walafrid Strabo, mnich z Reichenau, zauważył, że dla Iroszkotów „obyczaj wędrowania stał się niemal drugą naturą" (consuetudo peregrinandi iam paene in naturam conversa est - Vita s. Galli, c. 46). Owe peregrynacje w imię Chrystusa były często węclrówkami misyjnymi. Sto lat po chrystianizacji Irlandii mnisi iryjscy podjęli działalność misyjną i alkcję utwierdzania chrześcijaństwa wśród Anglosasów. Przenieśli także swą działalność na kontynent - do królestwa Franków i plemiennych państewek germańskich.

W północnej Anglii jeden $z$ mnichów klasztoru Iona, Aedan, założył w 635 r. klasztor na wyspie Lindisfarne, położonej przy wschodnim wybrzeżu Nortumbrii. Klasztor Linclisfarne stał się szyblio centrum życia religijnego i kultury piśmiennej. Opisujący sto lat później te wydarzenia Beda Venerabilis (zm. 735) zanotowal, że wiedza teologiczna Aedana i jego znajomość Biblii była szeroko znana. Pod kierunkiem tego opata-biskupa nie tylko mnisi i duchowni, ale nawet ludzie świeccy „studiowali Pismo Święte i uczyli się Psałterza”. Uczniowie Aedana zalkładali nowe ośrodki zycia religijnego w Anglii. Jednym z nich był podwójny (męski i żeński) klasztor Whitby, fundowany w 657 r. i kierowany przez Hildę, pochodzącą $z$ rodu królewskiego. Wykształcenie religijne zdobyła ona w Lindisfarne, słuchając nauk Aedana i innych mnichów. Hilda, jako ksieni Whitby (657-680), kierowała studiami biblijnymi i lekturami swoich mnichów i mniszek. To ona przyjęła do klasztoru i wykształciła pierwszego poetę anglosaskiego Caedmona, który wcześniej był parobkiem klasztornym. Caedmon jak przekazuje Beda Venerabilis - opisał wierszami historię zbawienia, straszne 
sceny Sądu Ostatecznego, przerażające kary piekielne i błogosławieństwo wiecznego życia w niebie.

Chrześcijaństwo wprowadziło do Irlandii kulturę piśmienną. Rozwinęła się ona w ośrodkach klasztornych i miała własne, wyraźne oblicze. Kultura piśmienna wczesnośredniowiecznej Irlandii była przede wszystkim kulturą monastyczną.

Szczególnym szacunkiem cieszyło się Pismo Swięte - jako Słowo Boga otaczano je czcią, pilnie czytano, studiowano i komentowano, by lepiej zrozumieć jego treść. Egzegeza - komentowanie Biblii było jednym z najważniejszych obszarów działalności mnichów iryjskich w VII i VIII w. Pisano komentarze do poszczególnych ksiąg biblijnych i do całego Pisma Świętego. Niektóre $z$ tych dziel, jak „De mirabilibus Sacrae Scripturae” (,O cudownościach Pisma Swiętego”), miały znamiona samodzielności i oryginalności. W klasztorach iryjskich studiowano dzieła Ojców Kościoła. Powstawały tu utwory hagiograficzne, opisujące życie i cuda wielkich założycieli klasztorów i świętych mnichów. Rozkwitała tutaj również poezja religijna, która zachowała rodzime formy celtyckie i posiadała często wyszukane słownictwo.

Przykładem tego jest hymn kościelny „Altus prosator”, przypisywany św. Kolumbie $z$ klasztoru Iona. Są w nim słowa rzadkie, jak „prosator” zamiast „creator" (stwórca), neologizmy, grecyzmy (jak „polyandria” w znaczeniu groby) i hebraizmy (jak „iduma” - ręka). Jest to ślad eruclycji mnichów iryjskich, przede wszystkim pilnego wertowania słowników.

Piśmiennictwo religijne mnichów iryjskich od VII w. tworzyło ważną część literatury wczesnośredniowiecznej Europy.

Łacina - język Ksiąg Świętych i liturgii - była dla mnichów iryjskich językiem całkowicie obcym. Zatem uczono się go pilnie i wytrwale. Już św. Patryk według późniejszej legendy hagiograficznej - miał sam napisać „,365 lub więcej abegetoria (tj. abecedaria)", a więc wzorniki-elementarze, służące do nauki języka i pisma łacińskiego. Sw. Kolumba - jak stwierdza jego biograf Adamnan wiele godzin poświęcał czytaniu i pisaniu. Studia językowe, gramatyczne stanowiły ważną część zajęć intelektualnych mnichów. Podejmowane najpierw w celu poznania języka Biblii i dzieł religijnych, prowadziły do znajomości autorów antycznych, a przynajmniej fragmentów ich dzieł. Św. Kolumban, który długi czas był mnichem w Bangor i tutaj zdobyl wykształcenie oraz formację monastyczną, nie tylko pisal porl kierunkiem swego nauczyciela komentarz do Psalmów - o czym informuje biograf świętego, Jonasz z Susa (Vita Columbani I, 3). Zapewne również w Bangor poznał on część utworów pisarzy antycznych, może za pośrednictwem dzieł gramatyków łacińskich. Znajomość pisarzy antycznych bowiem widoczne jest w pismach św. Kolumbana.

Mnisi iryjscy rozwinęli własny, charakterystyczny styl łacińskiego pisarstwa. Odznaczał się on wyszukaną formą i skomplikowanym sposobem wyrażenia myśli. Przejawiali też zamiłowanie do słów rzadkich, wyszukanych, sami tworzyli neologizmy. Być może, wszystko to należy tłumaczyć wpływem rodzimych tradycji literackich. Jak się wydaje, chrześcijańska literatura Irlandii tego czasu była wynikiem przenikania się i stopienia tradycji rodzimych oraz dziedzictwa łacińskiego. 
Jeszcze jedna dziedzina ówczesnej wiedzy absorbowała uwagę mnichów iryjskich. Była to komputystyka, studia matematyczno-astronomiczne, których celem było obliczenie właściwej daty Wielkanocy (Kościól celtycki różnił się tym od Kościoła rzymskiego) i według tej daty ułożenie rocznego kalendarza świąt kościelnych, $z$ niedzielami włącznie.

Obok wymienionych już dziedzin działalności pisarskiej i aktywności intelektualnej mnisi iryjscy zajmowali się rocznikarstwem, zapisywali i opracowywali genealogie rodów królewskich, rodzimą poezję bohaterską i podania. Już od VI w. rodzimy język Irlandii (zwany goidelskim) znalazł swe miejsce w piśmiennictwie. Później, w VII i VIII w., teksty pisane przez mnichów w języku rodzimym są coraz liczniejsze. Szczególnie interesująca jest tutaj poezja świecka, pokazująca rzadką wówczas wrażliwość mnichów iryjskich, surowych ascetów, na świat natury - otaczającą ich przyrodę, zwierzęta. Pogodny i ciepły nastrój stwarza wiersz o Pandurze, kocie skryby iryjskiego, albo inny, opisujący pracę kopisty w lesie (zob. niżej). Oba te wiersze, napisane w języku rodzimym, zostały zapisane przez mnichów-kopistów na końcu tekstów lacińskich.

Dla tradycji europejskiej kultura Irlandii to przede wszystkim kultura ksiażki. To, czego Iryjczycy dokonali w zakresie piśmiennictwa i kształcenia przeszło do wspólnego dziedzictwa kultury europejskiej. Kultura łacińska i kultura książki znalazła we wczesnym średniowieczu swą ojczyznę w klasztorach Irlandii.

Od VI w. począwszy ludzie wędrowali do klasztorów iryjskich, by zdobywać tu wiedzę i pogłębiać swe wylkształcenie religijne. Beda Venerabilis pisał o sławie i popularności iryjskich szkół klasztornych wśród Anglosasów. Wielu młodych ludzi - twierdził Beda - „możnych i innych”, udawało się do Irlandii, by odbyć studia religijne i praktykować życie ascetyczne. Mnisi iryjscy przyjmowali ich życzliwie, udzielali chętnie gościny bez zapłaty i dawali im książki do czytania i nauki. Slawa szkół Irlandii przyciągała również Franków. W połowie VII w. kształcił się tu Agilbert, późniejszy biskup Dorchester, a potem Paryża. Kiedy zaś św. Gertruda, pochodząca $z$ możnego rodu frankijskiego majordomów Austrazji, została ksienią klasztoru w Nivelles, sprowadzila $z$ Irlandii mnichów przygotowanych do „wykładania dzieł prawa Bożego” - tj. Biblii (ad docendum divini legis carmina - Vita S. Gertrudis, 2).

Legendy hagiograficzne - popularny wówczas gatunek piśmiennictwa religijnego, nie tylko w środowiskach klasztornych - stwierdzają, że książka, czytanie i pisanie związane są mocno $z$ działalnością wielkich świętych Irlandii.

Według żywotów św. Patryka książka i praca pisarska zajmowały ważne miejsce w jego akcjach misyjnych. Do dzialań apostolskich tego świętego należały własnoręcznie pisane księgi święte, które Patryk ofiarowywał zakładanym przez siebie kościolom; pisał także karty $z$ alfabetem („abegetoria”, „abecedaria"), które służyły do nauki czytania i pisania jego iryjskim uczniom. Być może, że owe „abegetoria” - alfabety oznaczały - jak sądzi jeden ze współczesnych badaczy - „teksty podstawowe”, elementarne, rodzaj „alfabetu wiary” (jak Credo, Pater noster, Dekalog).

Przykład żywotów św. Patryka pokazuje, że pisanie uznawane było przez hagiografów iryjskich za rodzaj apostolstwa. Przynosiło ono pożytek wiernym, piszącemu zaś dodawało blasku i zaslug świętości. 
Księgi towarzyszyły świętym i czyniły cuda. W jednym $z$ żywotów św. Patryka - napisanym w końcu VII w. przez mnicha Muirchú znajduje się opowieść o „pojedynku wiary” jaki odbył się między druidem a ochrzczonym przez Patryka Benignusem, ulubionym jego uczniem. Druid założył szaty kaplańskie św. Patryka i trzymał w ręku jego Biblię, Benignus zaś miał tunikę druicla i jego księgę. Obaj zostali zamknięci w drewnianej chacie, którą podpalono. Benignus ocalał̇, spłonęła jedynie tunika i księga druida. Natomiast druid zginął w płomieniach, a ocalały szaty kapłańskie i święta księga Patrylka. Opowieść ta bardzo dobitnie ukazuje przekonania mnichów iryjskich o mocy księgi świętej i szat kapłańskich - spotęgowaną jeszcze faktem uzywania ich przez św. Patryka.

Dużo informacji na temat szacunku i czci, jakie w środowiskach klasztornych Irlandii budziły księgi, ich czytanie i kopiowanie, przekazują legendy hagiograficzne o św. Kolumbie $z$ lona (zm. 597). Według nich każdemu $z \operatorname{trzy-}$ stu założonych przez Kolumbe klasztorów pozostawil on własnoręcznie przepisany ewangeliarz. W żywocie św. Kolumby - napisanym w końcu VII w. przez Adamnana, jednego $z$ następców świętego na urzędzie opackim w klasztorze Iona - książki zajmują ważne miejsce: święty zajęty byl ciągle czytaniem i kopiowaniem ksiąg. Smierć zastała św. Kolumbę przy kopiowaniu psałterza, który ukończył już jeden $z$ jego uczniów i następca na urzędzie opata w Iona.

Adamnan pisze równiė̇, że kart ksiąg pisanych ręką św. Kolumby nie mogła zniszczyć woda. Zatopione przypadkiem w rzece i wydobyte po jakimś czasie, nie byly uszkodzone ani zbutwiałe, pozostały suche i nienaruszone. Ze św. Kolumbą związany jest tez jeden $z$ najstarszych rękopisów iryjskich, słynny psałterz z pierwszej polowy VII w., zwany „Cathach” („Bojownik”). Jego powstanie późniejsza legenda hagiograficzna przypisała Kolumbie. Oto święty skopiował potajemnie ten psałterz $z$ egzemplarza, który należał do innego świętego - Finniana. Finnian dowiedział się o tym i domagał się przed królem wydania kopii. Kolumba nie chciał tego uczynić. Dowodzil, że oryginał nie stracił na wartości przez jego skopiowanie, a poza tym nie można wzbraniać kopiowania i rozpowszechniania świętego tekstu. Wówczas król wydał słynny wyrok: „Jak cielę należy do krowy, tak kopia należy do księgi". Kolumba przeklął króla za ten wyrok i doszło do walki między rodem króla a rodem świętego. Była to - jak pisał Heinrich Böll w Dzienniku irlandzkim - ,jedyna bitwa o prawa autorskie, jaką kiedykolwiek stoczono na świecie".

Opowieści o gorliwym pisaniu ksiąg przez świętych mężów - a również o cudownej mocy ksiąg - znajdujemy również w innych iryjskich legendach hagiograficznych, Przedstawiały one pewien wzór, ideał mnicha i świętego. Pisanie, kopiowanie ksiąg należało do jego podstawowych zadań i zasług.

Określenie „scriba” - pisarz/kopista było tytułem zaszczytnym; wyróżniało ono i zdobiło świętego oraz mnicha bardziej może jeszcze aniżeli urząd kościelny. Oto kopista jednego $z$ ewangeliarzy iryjskich z początku IX w., Mac Regol z Birr, podpisal się w tym kodeksie jako „skryba i biskup opat” (scriba et episcopus abbas). $Z$ dumą zestawił zajęcie skryby $z$ funkcją opata-biskupa, stawiając kopiowanie na pierwszym miejscu. Częściej również, aniżeli w innych krajach łacińskiego chrześcijaństwa tego czasu, kopiści iryjscy notowali swe imiona 
w przepisywanych kodeksach. Zwykle dodawali do tego prośbę do czytelnikaużytkownika o modlitwę.

Czasem pojawiają się na końcu przepisywanego tekstu również inne doclatki kopisty. W jednym $z$ kodeksów zawierającym dzieło gramatyka rzymskiego Pryscjana (V/VI w.), skopiowanym zapewne w klasztorze Bangor, kopista zapisał na końcu wiersz w języku ojczystym („Skryba w lesie”): „Wokół otacza mnie leśna gęstwina, dochodzi do mnie głośna pieśń kosa; przy moim pergaminie gęsto zapisywanym dźwięczą śpiewy ptaków. Z wierzchołka drzewa jasnym głosem nawołuje mnie kukułka, w szarym płaszczu piór. Zaprawdę - niech strzeże mnie Bóg! - jak pięknie pisze się pod dachem lasu".

W rękopisach iryjskich po raz pierwszy kopiści zaczęli również zapisywać uwagi o trudzie pisarskim i zmęczeniu: „Tres digiti scribunt et totum corpus laborat" ("Trzy palce piszą, a całe ciało pracuje") - było to powiedzenie, powtarzane później przez wielu kopistów w średniowieczu. Spotyka się też wyznania skrybów - pisane w języku ojczystym - bardziej osobiste: „Będę wspominał, o Chryste, że pisałem to dla ciebie, ponieważ dziś czuję się bardzo zmęczony. Niedziela wieczór” lub „Błogosławieństwo dla duszy Fergusa [kopisty]. Amen. Bardzo mi zimno".

Iryjskich kopistów urzekała możliwość pisania tekstu różnym alfabetem. W „Księdze z Armagh” („Book of Armagh”, początek IX w.) skryba Ferdomnach napisał kunsztowną subskrypcję łacińską greckimi literami. Tutaj też łaciński tekst „Pater noster” w Ewangelii św. Mateusza napisano greckimi literami. Podobnie w jednej z kopii „Żywotu św. Kolumby” Adamnana, którą sporządził Dorbene $z$ Iona, laciński tekst modlitwy Pańskiej na końcu tekstu napisany został grecką majuskułą.

W każdym klasztorze znajdowała się komora (zwykle drewniana chata) do przechowywania ksiąg (irl. techscrepta-dom książek). Gromadzono tu również pergamin przygotowywany przez samych mnichów w klasztorze, tabliczki do pisania, narzędzia pisarskie i atramenty.

Do przechowywania i transportu książek służyły skórzane torby (łac. sacculi. irl. thiaga), które noszono na ramieniu. Według legendy hagiograficznej w swej podróży do Rzymu spotkal św. Patryk pielgrzymów iryjskich, którzy nieśli swe książki włożone za pasem. Święty darował im swoje skórzane okrycie, by mogli zrobić sobie torby na książki. Św. Kolumba nosił swoje książki również w torbie, którą sam zrobił. Takie torby $z$ książkami wisiały na ścianach cel mniszych i w „domu ksiązek” klasztoru. Wedlug legendy w chwili śmierci św. Longorada spadły ze ściany torby na książki w całej Irlandii, również w celi św. Kolumby.

Cenniejsze, ozdobne księgi - służące do wspólnego użytku liturgicznego, a nie codziennego mnichów - przechowywano w skrzynkach (łac. capsae librorum, irl. cumdach), przypominających relikwiarze. Zachowało się kilka takich skrzynek na książki, pokrytych srebrną blachą, wysadzanych ozdobnymi kamieniami, prawdziwe dzieła sztuki kowalstwa artystycznego. Wspominaja o nich także iryjskie opowieści hagiograficzne.

Kontakty kościelne Irlandii z Galią, Italią (Rzymem) i Hiszpanią przyczyniły się do napływu dzieł religijnych i gramatycznych-literackich, które kopiowano na miejscu. Służły także jako wzorzec dla stylu pisma. Już w V w. dotarło do 
Irlandii późnorzymskie pismo książkowe, zwane półuncjałą, używaną w kodeksach chrześcijańskich. Tutaj pismo to zostało w sposób samodzielny przetworzone i w tej zmienionej postaci rozpowszechnione również wśród Anglosasów. Było to tzw. pismo insularne. Mnisi iroszkoccy i misjonarze anglosascy przenieśli to pismo do ośrodków klasztornych na kontynencie, jak Bobbio, Sankt Gallen i Ratyzbona.

Wytworzyły się ponadto dwie odmiany pisma insularnego: 1) półuncjała insularna - pismo solenne, używane głównie do ksiąg liturgicznych i biblijnych, ewangeliarzy i psałterzy, oraz 2) minuskuła insularna - pismo mniej kaligraficzne, stosowane do książel i tekstów codziennego użytku mnichów; pisano nią również małe ewangeliarze „kieszonkowe”, zabierane w drogę przez pielgrzymujących mnichów i misjonarzy. W tytułach lub tzw. stronach monogramowych pojawia się nadto ozdobna kapitała, różniąca się od antycznej swoistym kształtem, który przypomina pismo runiczne. Pismo insularne miało tak charakterystyczny kształt, że późniejsi bibliotekarze wydzielali kodeksy nim pisane w osobne grupy (,scotica”, „scotaica”). Tak zrobil też bibliotekarz klasztoru Sankt Gallen, który w katalogu z połowy IX w. wydzielił „libri Scottice scripti” („księgi napisane po iroszkocku”).

Pismo insularne wygasa na kontynencie około $800 \mathrm{r}$. W Anglii już w IX w. widoczne są wpływy minuskuły karolińskiej. Wprowadził ją jednak tutaj i upowszechnił normański podbój Anglii (1066). Natomiast w Irlandii półuncjała i minuskuła insularna używane były dalej. Stopniowo zaczyna dominować tutaj minuskuła insularna, która w XI-XII w. stała się pismem bardziej kaligraficznym o ostrych, surowych i czytelnych kształtach. W takiej formie minuskuła insularna przetrwała do czasów nowożytnych. Wywarła również wpływ na pismo drukowane Irlandii.

Przykładem wczesnego stadium sztuki pisarskiej iryjskich kopistów jest „Cathach" - psalterz z pierwszej połowy VII w., przypisywany św. Kolumbie (zob. wyżej). Jest on starannie i czytelnie pisany półuncjałą, z oszczędną ornamentyką inicjałów. Pojawiła się już tutaj typowa dla późniejszych rękopisów iryjskich forma, a mianowicie trójkątnie zbudowana grupa inicjałowa. W ten sposób rozpoczyna się każdy psalm w tym kodeksie.

W ciągu VII i VIII w. sztuka książki skryptoriów iryjskich doszła do niebywałego rozkwitu. Rodzime tradycje sztuki celtyckiej oraz kontakty ze sztuką Anglosasów i sztuką łacińskiego Zachodu (szczególnie frankijską) artyści iryjscy potrafili wchłonąć i przetworzyć w oryginalne i wybitne dzieła malarstwa książkowego. Zachowało się kilka ewangeliarzy, które należą do najwybitniejszych pomników Kościoła celtyckiego wczesnego średniowiecza. Najsłynniejsze $z$ nich to „Księga $z$ Durrow”, pochodząca $z$ drugiej polowy VII w., „Księga z Lindisfarne" powstała w tym iryjskim klasztorze w Northumbrii ok. $700 \mathrm{r}$. i najmłodszy $z$ tych ewangeliarzy „Księga $z$ Kells” $z$ późnego VIII w. (ok. 800 r.).

Pojawiają się $w$ tych ewangeliarzach ozdobne, pełne symboliki rodzimej i chrześcijańskiej (krzyzi) tzw. strony dywanowe, które przypominają plaszczyznę dzieła złotniczego. Występują na kartach tych ksiąg symbole czterech ewangelistów lub postacie ewangelistów, zredukowane do najprostszych form. Spotyka się w nich ponadto tzw. strony monogramowe, umieszczane na początku tekstu Ewangelii. Charakterystyczną formą ornamentyki tych kodeksów są 
wstęgi z plecionką geometryczną lub zwierzęca; częsty jest motyw stylizowanych zwierząt lub postaci ludzkich, splecione ciała zwierzęco-ludzkie, motyw wirujących spirali, rozety, czerwone kropki wokół liter w inicjałach. Była to ornamentyka pełna znaczeń symbolicznych, czytelnych dla mnichów tej epoki. Owa ornamentyka ksiag świętych - razem $z$ symbolami lub postaciami ewangelistów - nie pełnila funkcji dekoracyjnych. Miała ona przenosić czytelnikaużytkownika tych ksiąg w inną rzeczywistość - w sferę „sacrum”. Szczególnie początek lektury tekstu świętego - dzięki symbolom i świętym postaciom miał pobudzać do głębokiej medytacji; miał oderwać mnicha od rzeczywistości tego świata, aby mógł on zgłębiać boskie tajemnice.

Gerald $z$ Walii (1147-1223) w swoim znakomitym opisie Irlandii (Topographia Hibernica) wspomniał o jednym takim ozdobnym Ewangeliarzu. Oglądał go Gerald w klasztorze Kildare, założonym przez św. Brygidę. „Wśród wszystkich cudowności Kildare - pisze on - nic nie wydaje się bardziej cudownym, niż owa zadziwiająca księga $z$ czasów św. Brygidy, napisana, jak powiadają, pod dyktando anioła". Bowiem mnichowi wykonującemu tę księgę - jak informuje dalej Gerald - ukazal się we śnie anioł i pokazał mu wzory stron, które miał przepisać i ozdobić. Mnich zaś nazajutrz, wsparty modlitwami św. Brygidy, odtworzył te wzory dokładnie w swej księdze. „Tak więc - kończy Gerald swą opowieść o cudownym Ewangeliarzu - dzięki pokazywaniu przez anioła wzorów, dzięki modlitwom Brygidy i naśladowaniu przez skrybę niebieskich wzorów księga ta została napisana".

Najazdy wikingów w IX i X w. zniszczyły biblioteki Irlandii. Klasztory były nierzadko plądrowane wiele razy i niszczone. Książki najeźdźcy palili lub topili, jak wspominają ówczesne relacje źródłowe. Część kodeksów uciekający mnisi zabrali ze sobą do innych klasztorów. Wiele $z$ nich znalazło się w klasztorach na kontynencie. Kiedy na początku XI w. król Brian Borama dążył do odrodzenia zycia religijnego Irlandii nakazał duchownym kupować księgi „za morzem”, bowiem te, które były niegdyś w kraju, zostały zniszczone przez wikingów.

Czas rozkwitu kultury chrześcijańskiej w Irlandii przypadł na stulecia między VI a IX w. Dla chrześcijan Europy wczesnego średniowiecza ta wyspa położona na krańcach Zachodu, była „lumen gentium” - „światłem narodów”.

\section{Przypisy bibliograficzne:}

Tekst ten jest częścią przygotowanego do druku zarysu podręcznikowego na temat kultury piśniennej łacińskiego średniowiecza.

O wczesnym chrześcijaństwie w Irlandii i dziejach Kościoła iryjskiego:

A. Angenendt, Das Frühmnittelalter. Die abendländische Christenheit von 400 bis 900, Stuttgart-Berlin-Köln 1995 (wyd. 2), s. 203-223; L. Bieler, Irland. Wegbereiter des Mittelalters, Olten-Lausanne-Freiburg in Br. 1961; H. Chadwick, The Age of Saints in Early Celtic Church, Oxford 1961; K. Hughes, The Church in Early Irish Society, London 1966; R.E. McNally, Die keltische Kirche in Irland, [w:] K. Schäferdiek (ed.), 
Die Kirche des frühen Mittelalters (Kirchengeschichte als Missionsgeschichte 2, 1), München 1978, s. 91-115; F. Prinz, Peregrinatio, Mönchtum und Mission, w: ibidem, s. 445-465; M. Richter, Irland in Mittelalter. Kultur und Geschichte, Stuttgart-BerlinKöln 1983.

Ciągle interesująca jest praca o św. Patryku S. Czarnowskiego, Kult bohaterów i.jego spoteczne podłoże. Swiety Patryk bohater narodowy Irlandii (Dziela S. Czarnowskiego, t. IV), Warszawa 1956 (thumaczenie z książki wydanej po francusku w 1919 r. w Paryżu); por. także: R. P. C. Hanson, Saint Patrick. His Origins and Career, Oxford 1968; J. Strzelczyk, Apostolowie Europy, Warszawa 1997, III. Boski bard. Patryk - apostol Irlandii (s. 62-76). Zbiór tekstów źródłowych w thumaczeniu polskim: Sw. Patryk. Pisma i najstarsze żyoty. (Źródła monastyczne, 29), Tyniec-Kraków 2003, ze wstępem i w opracowaniu J. Strzelczyka.

O znaczeniu Kościoła iryjskiego, kultury monastycznej Irlandii dla świata chrześcijańskiego wieków średnich: A. Angenendt, Monachi peregrini. Studien zu Pirmin und den monastischen Vorstellungen des frühen Mittelalters, München 1972; H. B. Clarke, M. Brennan (ed.), Columbanus and Merovingian monasticism, Oxford 1981; L. Gougaud, Les Saints irlandais hors d'Irlandie, Louvain-Oxford 1936; H. Löwe (ed.), Die Iren und Europa im frühen Mittelalter, t. 2, Stuttgart 1982; P. Ni-Chatháin, M. Richter (ed.), Irland und Europa/Ireland and Europe. Die Kirche im Frühmittelalter/The early Church, Stuttgart 1984; J. Strzelczyk, Iroszkoci w kulturze średniowiecznej Europy, Warszawa 1987.

Ważny tom źródeł w tłumaczeniu polskim: $\dot{S}_{w}$. Kolumban, Pisma. Jonasz z Bobbio, Zywot Kolumbana. (Pisma starochrześcijańskich pisarzy, t. LX), Warszawa 1995, z obszernym wstępem i komentarzami J. Strzelczyka.

O kulturze piśmiennej Irlandii we wczesnym średniowieczu: B. Bischoff, Wendepunkte in der Geschichte der lateinischen Exegese in Frühnittelalter, w: tego $\dot{z}$, Mittelalterliche Studien, Bd. 1, Stuttgart 1966, s. 205-275; M. Dillon, N. K. Chadwick, Ze swiata Celtów, Warszawa 1975, rozdz. 8: Celtyckie chrześcijaństwo i jego piśniennictwo; A. Harvey, Early Literacy in Ireland: The Evidence trom Ogam, "Cambridge Mediaeval Celtic Studies" 14 (1987), s. 1-14; K. Hughes, The Distribution of Irish Scriptoria and Centres of Learning from 730 to 1111, w: N. K. Chadwick (ed.), Studies in the Early British Church, Cambridge 1958, s. 243-273; M. Lapide, R. Sharpe, A Bibliography of Celtic-Latin Literature 400-1200, Dublin 1985; P. Ni-Chatháin, M. Richter (ed.), Irland und Christentum/Ireland and Christendom. Bibelstudien und Mission/The Bible and the Missions, Stuttgart 1987; C. Plummer (ed.), Vitae Sanctorun Hiberniae, 2 tomy, Oxford 1910; E. Potkowski, Ksiązka w kregu sacrum - przykład Irlandii we wczesnym średniowieczu, "Przegląd Humanistyczny” 40 (1996), z. 1, s. 53-68; R. Sharpe, Medieval Irish Saints' Lives. An Introduction to Vitae Sanctorum Hiberniae, Oxford 1991;

J. Stevenson, Literacy in Ireland: the Evidence of the Patrick Dossier in the Book of Armagh, w: R. McKitterick (ed.), The Use of Literacy in Early Medieval Europe, Cambridge 1990, s. 11-35.

Kodeksy i sztuka książki Irlandii we wczesnym średniowieczu: J. J. G. Alexander, Insular Manuscripts, 6th to the 9th Century, London 1978; G. Henderson, From Durrow to Kells. The Insular Gospel-books 650-800, London 1987; Irische Kunst aus drei Jahrhunderten. Thesaurus Hiberniae, Mainz 1983 (katalog wystawy w Kolonii i Berlinie); C. Nordenfalk, Insulare Buchmalerei, München 1977; O. K. Werckmeister, 
Irischnorthumbrische Buchmalerei des 8. Jahrhunderts und monastische Spiritualität, Berlin 1967.

Faksymilowe wydanie ewangeliarzy iryjskich: The Book of Durrow - Evangeliorum quattuor Codex Durmachanus, 2 tomy, (ed.), A. A. Luce, G.O. Simms, P. Meyer, L. Bieler, Olten-Lausanne 1960; The Book of Kells - Evangeliorum quattuor Codex Cennanensis, (ed.), E. H. Alton, P. Meyer, G. O. Simms, 3 tomy, Olten-Bern 1950; The Lindisfarne Gospels, (ed.), M. Brown, Luzern 2003. 